\title{
ORGANIZATION AND MATERIAL SUPPORT \\ OF THE EDUCATIONAL PROCESS \\ AT PRIMARY EDUCATION INSTITUTIONS FOR ADULTS \\ IN SUMY REGION IN THE 20-30s OF THE XXth CENTURY
}

\author{
Larysa Yepyk \\ Candidate of Historical Sciences, Associate Professor, \\ Sumy State Pedagogical University named after A. S. Makarenko, Ukraine \\ e-mail: larusyabarabash2017@gmail.com, orcid.org/0000-0001-5160-6529 \\ Nataliia Petrenko \\ Postgraduate Student, \\ Oleksandr Dovzhenko Hlukhiv National Pedagogical University, Ukraine \\ e-mail: npetrenko1995@gmail.com,orcid.org/0000-0003-3781-6372
}

\section{Summary}

The article considers the questions of organization and methodological and material support of the educational process at primary schools of adult education in Sumy region in the 20-30s of the XX century. Based on the documents of the State Archives of Sumy region, the position of the points of liquidation of illiteracy in a certain period is analyzed and their financial and methodological support, the process of organizing student learning, forms and methods of teaching is characterized. There are also quotations from documents that fully illustrate the issue raised in the article.

The authors of the article conclude that despite the insufficient financing and an imperfect system of material support for adult primary education institutions, a campaign to eliminate illiteracy had a positive result, which was manifested in increasing the number of literate people in the Sumy region, who learned to read and write in Ukrainian, which was, in its turn, of great importance for awakening the national consciousness of the Ukrainian population.

Keywords: the policy of illiteracy elimination, illiteracy, primary adult education, primary schools for adults, Sumy region.

\section{DOI: https://doi.org/10.23856/3880}

\section{Introduction}

Ukraine has a huge historical experience in organizing of a campaign to eliminate illiteracy in the 20-30s of the XX century, which requires meticulous and unbiased analysis. In addition to the organization of the educational process, the development of curricula, the problem requires the disclosure of the organization and material support of the teaching process. The illiteracy of the population in Ukraine at the beginning of the XX century was a significant social problem, the solution of which was a necessary condition for the further development of the society. The industrialization of the country required a huge number of literate workers, who were recruited from the multimillion mass of illiterate peasants.

The ignorance of the masses was an obstacle to economic development, as the industrial development of the state required educated workers. In particular, F. Liszt believed that education, science and culture are the most profitable and promising for the investment and that the state, which seeks for overcoming economic and political backwardness should take care of these 
areas, sometimes even neglecting the interests of the society (Borysenko \& Telehuz, 2012: 8). The elimination of illiteracy was also conditioned by the pedagogical teachings of the Bolsheviks and was determined by the political goal of creating a new type of society on the basis of an educated working-class and peasant population with a stable socialist consciousness.

The policy of eliminating illiteracy was actively implemented on the territory of Ukraine, and a wide range of archival documents gives the reason to believe that this political campaign was successful in Sumy region, too.

The solution of the urgent problems in the field of public education began on the first days of the Soviet state. Public policy in this area was largely a continuation of progressive reforms initiated by the advanced public in the pre-revolutionary period, but not completed for some historical reasons. The first decisions and measures of the Soviet government were based on the achievements of domestic pedagogical theory and practice, but made them more radical.

It is very important to understand in more details the organization of education in primary schools for adults and their logistics.

\section{Organization of the educational process at schools for adults}

The education of the illiterate was conducted through a network of specially created educational institutions that provided basic literacy for the general population. The network of such educational institutions consisted of institutions in which the educational process was carried out directly: literacy schools, schools for the illiterate, single-group study places and Sunday schools (Antoniuk, 2004: 90).

In general, the topic of eliminating illiteracy in the 20-30s of the XX century was raised in the works of such researchers as Antoniuk T., Boyko O., Borisenko V., Hololobov V. and others. The theme of illiteracy elimination and Ukrainianization in Sumy Region was researched by Korogod B. and Korogod G. in their works. Petrova J., Tymchuk L., Hololobov V., Boiko O. studied the question of organization of teaching and learning during the implementation of the campaign of illiteracy elimination as well. However, thorough research as for organization of the educational process at schools for adults in Sumy region in the 20-30s of the XX century is currently lacking.

It is clear that the initial period of elimination of illiteracy was characterized by the rapid development of a network of special points. One of the unfinished issues was the lack of schools for the illiterate (Leshchenko, 1969: 80). Such premises as folk houses, clubs, churches and even private buildings and rooms at industrial enterprises and administrative establishments were given for literacy classes. Initially, adult educational institutions were divided into 3 types of schools. The most common were public schools for the elimination of illiteracy of two degrees, which were organized in large villages and cities. Thus, in the 1 st grade of schools they taught to read and count (adults for 6 months; adolescents for 7 and a half months).

At the 2nd grade schools, the illiterate studied according to the primary school program (the period of attendance was from 6 to 9 months). In parallel, there were schools of adult educational society "Down with illiteracy!" and various public organizations. They operated at clubs, reading rooms and red corners. The third type were clubs in which those who learned to read and write taught the illiterate. They were created in remote villages and hamlets, where there were no cultural and educational institutions (Molotkina, 1999: 58). Literacy schools were the main type of educational institution in the field of eliminating illiteracy and the first level of adult education. These institutions included adults and adolescents who could not read or write at all, as well as those who knew the letters but did not have reading skills (Tymchuk, 2015: 74). 
Over time, illiteracy elimination points began to be divided into four types, depending on the location and a group of students. The first two types included literacy schools for adults in villages and towns. The third and the fourth types were both rural and urban, but for adolescents.

The period of training in the first and second types of literacy centers (for adults) was 6 months with a 9-hour work a week, and 3 months with daily work, except Sunday. The period of study at schools of the third and fourth types (for adolescents) lasted 7 months with a 12-hour weekly load and 5 months with daily classes. The total course of study at the institutions for adults was 216 hours, and for adolescents 260 hours (Gasilov, 1967: 2).

Each of the types of points for illiteracy elimination had its own slope in the curriculum, which was determined by the type of settlement where the school was opened. Thus, in rural schools the literacy program was agricultural, in urban schools it was industrial. Depending on the sources of funding, adult education schools belonged either to public education bodies or to public organizations (Moroz, 1976: 113).

The period of study at schools for adult education in Ukraine mainly lasted: in rural areas from October to the beginning of spring field work, in cities it was all year round. The plans provided for 2 graduatings per year. The traditional school form of eliminating illiteracy in the early 20 s of the XX century was a classroom system of education.

The general purpose of any lesson at an adult primary school coincided with the main goal of the campaign to eliminating illiteracy. During each lesson, ideological and political education in the process of literacy was followed. However, at the same time, each individual lesson had its own purpose, objectives, character, type and structure (Boiko, 2015: 321).

In the 20s of the XX century the American system Dalton Plan partially penetrated the points of elimination of illiteracy, as well as the Soviet education in general. According to this form of education, students gathered in the morning to school in a "class-organization", where they, under the guidance of a teacher-consultant, made a plan for the day, and then worked independently. Student's work was recorded using a complex system: at the end of the lesson, students took a test, the results of which were entered into an individual card. Homework was missing. It was one of the most common school systems based on the principle of individual learning. The negative features of this system were: low level of discipline, lack of teacher's work with the whole class and the weak result at the end. At the schools of Ukraine and Russia in the 1920s, there were attempts to use the Dalton Plan as a form of "free learning", but it proved to be ineffective (Boiko, 2015: 322).

However, the insufficient amount of material and physical resources for the points of elimination of illiteracy in Ukraine in the 20-30s of the XX century raised the question of the need to develop new forms of elimination of illiteracy among the population.

Therefore, from the 1924-1925 school year, in rural areas of many provinces, such a form of work with the illiterate as individual and group education was becoming widespread. Its essence followed from the slogan "Literate, teach the illiterate!". In conditions of catastrophic shortage of teachers to eliminate illiteracy, in rural areas, the slogan took on an important meaning.

The essence of this form of organization of the educational process was based on the fact that education was organized in places where the number of illiterates was less than 15 . The societies of illiterate and a little literate were organized in the number from 2 to 15 people. Training with several or even one illiterate teachers conducted at home or in the house of one of the students (Boiko, 2015: 322). 
The education of the illiterate through the individual-group form was carried out according to the curriculum for literacy and illiteracy schools. Recruitment of the illiterate was carried out by the group leaders themselves, primarily among members of their families and neighbors. Analyzing archival sources, we see that most age groups were divided as follows: from 12 to 15 years, from 16 to 20 years, from 21 to 41 years.

In the individual-group form of education, in contrast to the classroom, there was no clearly defined time of classes and terms of study. The transfer of individual-group students from the level of illiterate to a little literate took place on the basis of test examinations established for literacy and low literacy schools. "Liquidators" or group leaders were appointed by the village council. They were just councils' activists from among more or less educated and suitable for this work people. General management of the educational process, providing group leaders with the necessary literature and teaching aids was carried out by teachers of local schools (Petrova, 2010: 14).

In our opinion and the belief of researchers, the form of individual and group training in rural areas is one of the best ways to eliminate illiteracy, because it gave the peasants the opportunity to learn to read and write without leaving his farm.

Individual-group form of literacy training was also used among the so-called seasonal workers and day laborers to eliminate illiteracy. Individual-group training for work among them is convenient because it does not require a particularly strict school environment and can form a number of small in quantitative groups for literacy (from 3 to 10 people) (Boiko, 2015: 321).

The above opinion is confirmed by the researcher V. Hololobov, who points into some significant shortcomings of individual-group form of education: "In the circles of this form of education, the work was mainly carried out by non-professional teachers. Among them were citizens who did not even have a complete primary education. Students were not always provided with textbooks and necessary writing materials. During the training there were quite long breaks (sometimes for decades). All this negatively affected the educational process and led to a higher recurrence rate of illiteracy compared to other factors. And yet, for all its shortcomings, this form of education has enabled thousands of illiterates to realize their dream and desire for self-development" (Hololobov, 1998: 16).

The task of eliminating illiteracy was formally simplified by the fact that its solution did not require personnel with special knowledge in the field of education (qualified teachers). It was believed that literacy could be taught by those who were simply literate (Korohod \& Korohod, 1993: 16). In the first months of the campaign, experienced teachers, students of pedagogical schools, graduates of pedagogical courses and activists who could read, write and took the initiative to teach were involved in the education of the illiterate and low-literate population.

The campaign to eliminate illiteracy had the main goal of political education, and was classical and ideological in its nature. The specificity of the Soviet approach was the complete submission of the educational system to ideological guidelines. Solving the problem of mass illiteracy of the people also meant raising the problem of the language of education, providing the principle of teaching in the mother tongue (Borysenko \& Telehuz, 2012: 20).

Until the end of the $1920 \mathrm{~s}$, there were no stable curricula and programs for the elimination of illiteracy, which was associated with the simultaneous development of new educational content. With the permission of the People's Commissariat of Education of the Ukrainian SSR, schools could work according to the curricula drawn up by the education authorities or the schools themselves, which could be changed depending on specific conditions. In particular, in the program of the regional monthly seminar on the elimination of illiteracy, which was to take place in July 1924, one of the topics of classes "Development of complexes for 
schools for the illiterate" was mentioned (Prohrama kraiovoho seminaru dlia likvidatora nepysmennosti, 1924). It is clear from the text of the document that the lesson was to be conducted in a practical form. Thus, we can assume that it was just in such classes that adult school teachers were helped to develop curricula.

Nevertheless, there were some programs and guidelines for teaching illiterate and low-literate people: Boguslavskaya N. "Mathematical Deed (instructions for leaders)" (1922); Cooperstein W. "A Guide to Teaching Primary Mathematics to Adults" (1922); "Self-training guide for liknep workers (Liknep course at home). Second Edition" (1926) (Boiko, 2016: 13).

Among the documents stored in the State Archives of Sumy region we can find documents that contain statements for schools for adults and curricula for them. Thus, according to the regulations, literacy schools were to be opened wherever there was a need for them. The schools were maintained at the expense of the Department of Public Education and were accountable to this institution. Tuition was free for all students. Study time was set for each school separately depending on the wishes of students. Students aged 14 to 50 were admitted to the school, but it was desirable to form students aged 14 to 16 into separate groups (Polozhennia pro shkoly dlia doroslykh, 1920). The case in which this document is kept dates back to 1920. The document is written in Ukrainian. It does not contain any instructions for a specific district, so we have a reason to believe that the same directions were sent throughout Ukraine, where the process of eliminating illiteracy continued.

The program of schools for adults defines the main aspects of the educational process in primary schools. It is noted that the training of the first group (group for the illiterate) should last 2 months with a four-day training week. There should be three lectures on each school day. The task of this school is to teach an illiterate person to read, write and use the first four arithmetic operations, to give general information on local lore, to teach to read a book, to be interested in it, to spread human development and to acquaint with the person's place in the society (Prohrama shkil dlia doroslykh 1 stupenia, 1920). 48 hours of the curriculum were allocated for reading and writing, and 24 hours for arithmetic.

In general, the curriculum for the elimination of illiteracy provided a large number of areas of work, and that is why required extensive organized training of teachers and other educational workers. The quality of general education in the 1920s and early 1930s, in the terms of the campaign literacy was much lower than in pre-revolutionary Russia, because studies often spent kultarmiytsi (cultural workers) and activists, who didn't have a special teaching education. So, for these reasons, by the autumn of 1920 only by the bodies of the All-Russian Emergency Commission for the Elimination of Illiteracy in 26 provinces were created courses for teachers-liquidators of illiteracy (Kuksa, 2004: 106). Retraining courses and seminars were mandatory, in which teachers improved their own knowledge and skills regarding the education of the illiterate population.

It is important to remember that the goal of Soviet adult education is not national education with its influence on the formation of national identity, but political education. In accordance with the declared purpose the content of educational activities was determined. From the very beginning, it had a political orientation. The basis of the content of adult education was the native language, the history of Soviet reality and anti-religious principles. The approach to determining the content of education was proclaimed at the state level - political education, with no alternative in the context of the establishment of a totalitarian regime. If mass illiteracy was one of the obstacles to the effective propaganda of the Ukrainian national movement, so at Soviet times the elimination of illiteracy of the population turned into the propaganda of communism and the proletarian international movement. 


\section{Material and methodological support of adult primary educational institutions}

It is clear that a large number of adult primary schools required significant efforts to maintain and provide them.

The topic of financial and methodological support for the elimination of illiteracy in the $20-30$ s of the XX century has not been thoroughly studied by scientists. Some aspects of this question were mentioned in the works of Fisheva A., Svystovych S., Kozyr V., Danilchenko O. Material and methodological support of primary schools for adults in a certain period in Sumy region is not developed, but it was violated in some publications of the authors of this section.

As it was noted, depending on the sources of funding, illiteracy elimination points belonged either to public education bodies or to public organizations. Initially, the work for eliminating illiteracy was supposed to be carried out exclusively at the expense of the state. But the post-war devastation and famine, which worsened the financial situation of the population even more, also led to a sharp reduction in the elimination of illiteracy.

The pace of literacy work depended crucially on its funding. As with most other campaigns organized by the Bolshevik government, the elimination of illiteracy was largely due to public organizations and the teachers' enthusiasm. This convinced the appeal of the Ukrainian Central Executive Committee (the UCEC) to the relevant authorities in August 1923, in which it was straightly noted that the state could not take on all the costs of illiteracy eliminating (Svystovych, 2013: 77).

In this regard, they had urgently to look for other sources of funding for the campaign for eliminating illiteracy, to involve local authorities and public organizations into this work. Because of the limited capabilities of the state, most of the costs were put on the population of a region. The attitude of the population to the elimination of illiteracy remained unstable, so organizations had to pursue an active campaign policy (Danylchenko, 1999: 78).

The establishment of schools and points for the elimination of illiteracy and their work were financed partly from the state budget, from local councils and trade unions. In the first years of the NEP, the difficult economic situation made the state to give funding for the elimination of illiteracy fully to local authorities. In fact, the local budget could not support the struggle against illiteracy, as a result the number of existing adult education schools shortened sharply and the supply of textbooks and stationery deteriorated essentially.

Thus, in the early 1920s, funding for adult education schools was transferred to public organizations and the population. Schools were transferred to provide for trade unions, cooperatives and the "Down with Illiteracy" societies. A special tax and fines were represented in favor of illiteracy centers. So, if a person refused to learn to read and write, he had to pay a certain amount of money. There was also increased pressure on non-governmental organizations, whose members were forced to pay dues, hold two-day terms or week terms to raise funds to provide illiteracy centers.

Among the archival documents we find various information about the size of membership fees of members of the society "Down with illiteracy". In particular, the following amount of contributions was set for members of the Berezivka society: for cooperatives not less than 5 karbovanets, for members of trade unions 25 kopecks, for all citizens - 5 kopecks. In other branches of the company there was a division into entrance and monthly fees, which amount was to 10 kopecks and 5 kopecks accordingly (Zvit pro diialnist tovarystva "Het nepysmennist" imeni Lenina, 1926). Due to such measures, more than $90 \%$ of funds were received annually for the work of illiteracy elimination points (including almost half from public organizations). The rest of the funds came from the state budget (Kozyr, 2010: 237). 
Despite the help from the groups of the society "Down with illiteracy" and other public organizations, the points of liquidation of illiteracy were in a very difficult situation. Thus, in the statement about the work of the Government for the control of societies for political education in Konotop district for the third quarter of 1924 indicates that there was a lack of money not only to ensure schools for adults with necessary materials, but also on teacher salaries. In fact, in cities, most teachers were paid for their work, while in rural areas, teachers received absolutely nothing. Prom was not carried out because of a lack of financing (Doklad pro robotu Konotopskoi Okrpolitprosvity, 1924).

Archival documents contain a lot of information to confirm the facts about the difficult financial situation of teachers of illiteracy institutions. These are mostly written complaints or letters from teachers. There is an interesting letter from the teacher of Karabutovska school, F. Typko, to the Government for the control of the societies for political education in Konotop district, who asked for transfer to another school in Konotop district. The teacher noted that she did not have enough money paid by the state (15 rubles 75 kopecks) to rent an apartment and provide her own needs (Yepyk \& Petrenko, 2018: 1004).

There were also true enthusiasts of the teaching profession, who made a really huge effort to eliminate illiteracy. Despite the low level of wages, horrible living conditions, such teachers, as it is often today, worked for the idea. Despite all obstacles, the literacy instructors made every effort to maximize student involvement in the courses. Instructor Ivan (his surname is illegible in the document) reported on the consequences of his work: "I prove that the case of elimination of illiteracy in the village Holintsi does not hold, the population does not want to enter the literacy school voluntarily; meanwhile, a huge number of illiterate and low-literate people is counted - 1742 people per 5.5 thousand inhabitants. Due to such an indifferent attitude to education and not wanting to apply coercive measures, I chose the method to arouse interest in knowledge through lectures of scientific and educational content. The audience is gradually increasing and becoming more and more active" (Yepyk, 2016: 184).

In the complex of issues related to the organization of literacy centers, the provision with textbooks and stationery for both cadets and teachers has become urgent. This was at the expense of the state, but in insufficient numbers. Thus, the instructor for the elimination of illiteracy at the Konotop railway department reported that at Konotop station illiterate out of 5399 men was 924, out of 242 women was 52, the courses had to be attended by 126 men and 46 women. The inspector emphasized the complete absence of textbooks. He also requested 88 Ukrainian alphabets, 116 task books, 464 notebooks, 116 pencils, 100 pens, and 12 different alphabets. Instead, he received 6 alphabets, 25 workbooks, 100 notebooks and various alphabets (Doklad instruktora po likvidacii bezgramotnosti na Konotopskom zheleznodorozhnom uchastke, 1920).

At the end of 1922, textbooks in Ukrainian by the following authors: Tytarenko "Sonechko. Hramatyka" (Sunny. Grammar), Chepiha "Veselka. Persha chytanka pislia bukv" (Rainbow. The First Reading book after the Letters), Doroshkevych "Ukrainska literatura v shkoli" (Ukrainian Literature at School), Montessori "Metod naukovoi pedahohiky" (Method of Scientific Pedagogics), Schmidt "Psykholohiia maliuvannia" (Psychology of Drawing), Verykivskyi "10 narodnykh pisen" (10 folk Songs), Lebedintsev "Lichba i mira" (Counting and Measure) could be purchased in publishing houses (Yepyk, 2016: 185).

At one time with the publication of Ukrainian textbooks, the number of published literature in minority languages was increasing. The All-Ukrainian branch of the Central Publishing House of Nations reported that it was able to provide the necessary educational, popular scientific, political and other literature to educational institutions of national minorities quickly. Until the mid-1920s, the All-Ukrainian branch published 761 printed sheets in six minority 
languages, among which German (220 printed sheets) and Hebrew (260 printed sheets) were of real importance for Sumy Region (Yepyk, 2016: 185).

The analysis of textbooks and additional literature on the elimination of illiteracy in the period 1920-1927 showed the insufficiency of educational and methodological literature. To some extent, this need was covered by existing textbooks and manuals of previous years, but such educational literature was not suitable for the requirements of teaching illiterate people. Gradually, new requirements for educational literature were developed and new textbooks and manuals for the illiterate and low-literate appeared. However, the problem was not fully solved due to the lack of funds to provide literacy facilities with teaching aids, and that is why newspapers and magazines were often used to educate the illiterate.

Primers developed according to the complex programs contained materials for reading, writing and arithmetic's at the same time, thus replacing textbooks on those individual subjects. Therefore, it is impossible to call them primers in the modern sense of the word; it would be more accurate to talk about them as a primary textbook for adult at educational schools. But in order to adhere to the principle of historicism in the study, we found it to be appropriate to call them exactly as they were called at the time (Fisheva, 2015: 15).

Despite the desire of the peasants to learn in the Ukrainian language, they were sent a Russian-language "Bukvar dlya negramotnyh Elkinoj" (Primer for Illiterate by Elkina) (Borysenko \& Telehuz, 2012: 73). The three-month training, which was to learn to read, write, count and become politically literate, was not effective enough, as textbooks in a foreign language were incomprehensible to the villagers and living conditions did not contribute to the effective solution of educational problems.

At the points of illiteracy notebooks had to be sent as well. Moreover, the managers assured that 8 notebooks will be sent for one student for the whole academic year. However, the realities were not so positive. There were not enough notebooks and thus the students got only 2 for the whole year at best (Yepyk \& Petrenko, 2018: 1006).

As we can see, funding and material support for illiteracy centers was insufficient. There were not enough notebooks and the number of students exceeded the number of sent textbooks. In the first years of the campaign to eliminating illiteracy, both in Ukraine in general and in Sumy in particular, there was a lack of textbooks in the languages of national minorities. Accordingly, this affected not only the teaching of students, but also the quality of teaching the material of the teachers themselves.

\section{Conclusions}

In the 1920s and 1930s, the largest cultural campaign in the history of Europe was organized and conducted in the USSR. The policy of eliminating illiteracy was actively implemented on the territory of Ukraine, and a wide range of archival documents gives the reason to believe that this political campaign was successful in Sumy region as well.

The government made great efforts to eliminate illiteracy among the Ukrainian population, in particular, through the school system and creating a network of schools for adults. Analyzing the sources and works of researchers, we can conclude that the campaign to eliminating illiteracy has had very positive results: the population has become more educated and there has been a restoration of national culture.

From the first days of the campaign to eliminating illiteracy, a wide network of adult primary schools was established. Both professionals and enthusiasts were involved in the process of teaching. They wanted to teach literacy the illiterate population. The disadvantage of 
the rapid start of the learning process in the points of elimination of illiteracy was the lack of a unified teaching methodology and training programs. But teachers were able to adapt to the challenges of the times, and local education authorities issued the instructions on teaching and learning methods in literacy centers.

As we can see, in the early 1920s, funding for the work of illiteracy centers was transferred to public organizations and the public. Schools were transferred to provide for trade unions, cooperatives, and small groups the "Down with Illiteracy" societies. A special tax and fines were introduced in favor of illiteracy centers. There was also increased pressure on public organizations, whose members were forced to pay dues, hold two-day or seven-day work to raise funds. Quite a small percentage of the resources came from the state budget. The funds were never enough, teachers were not paid their wages, and textbooks were not received.

Despite the lack of literature and funding the campaign for eliminating the illiteracy in Sumy region in the 20-30s progressed very rapidly. From year to year the number of adult education points increased and the quality of education improved.

\section{References}

Antoniuk, T. (2004). Rozvytok osvitnoi systemy v USRR (20-ti-pochatok 30-kh rokiv) [Development of the educational system in the USSR (20's - early 30's)]. Istorychnyi zhurnal. № 6-7. [in Ukrainian]

Boiko, O. (2016). Orhanizatsiino-pedahohichni zasady likvidatsii nepysmennosti v Ukraini u 1920-1927 rokakh [Organizational and pedagogical principles of liquidation of illiteracy in Ukraine in 1920-1927]: avtoreferat dysertatsii kandydata pedahohichnykh nauk : 13.00.01. Uman: Umanskyi derzhavnyi pedahohichnyi universytet im. Pavla Tychyny. [in Ukrainian] Boiko, O. Stanovlennia form navchannia u protsesi likvidatsii nepysmennosti $v$ Ukraini 1920-1927 rr. [Formation of forms of education in the process of elimination of illiteracy in Ukraine in 1920-1927.] Naukovyi visnyk Melitopolskoho ped. universytetu. Seriia: pedahohichni nauky. Melitopol, 2015. Vyp. 1 (14). [in Ukrainian]

Borysenko, V. \& Teleguz, I. (2012). Natsionalna osvita i formuvannia ukrainskoi modernoi natsii u 1921-1934 rokakh: yevropeiski tendentsii ta radianski realii [National education and the formation of the Ukrainian modern nation in 1921-1934: European trends and Soviet realities]. Kyiv: Published by NPU M.P. Dragomanova. [in Ukrainian]

Danylchenko, O. (1999). Likvidatsiia nepysmennosti sered natsionalnykh menshostei pivdnia Ukrainy $v$ 20-kh pp. XX st. [Elimination of illiteracy among the national minorities of southern Ukraine in the 1920s]. Ukrainskyi istorychnyi zhurnal. № 3. [in Ukrainian]

Doklad instruktora po likvidacii bezgramotnosti na Konotopskom zheleznodorozhnom uchastke (1920) [Instructor's report on the elimination of illiteracy at the Konotop railway section]. Fond R-4565. Opys 1. Sprava 902. Derzhavnyi arkhiv Sumskoi oblasti, Ukraina. [in Russian] Doklad pro robotu Konotopskoi Okrpolitprosvity (1924) [Report on the work of the Konotop District Department of Political Education]. Fond R 4563. Opys 1. Sprava 964. Derzhavnyi arkhiv Sumskoi oblasti, Ukraina. [in Ukrainian]

Fisheva, A. (2015). Obshee obrazovanie vzroslyh na territorii RSFSR v 1930-1950-e gg. [General adult education in the RSFSR in the 1930-1950s]: avtoreferat kandidata istoricheskih nauk: 07.00.02. Sankt-Peterburg. [in Rusiian]

Gasilov, G. (1967). Likvidaciya bezgramotnosti v Sovetskoj Rossii. Stranicy vospominanij [Elimination of illiteracy in Soviet Russia. Pages of memories]. Russkaya rech. 1967. № 4. [in Rusiian] 
Hololobov, $V$. (1998). Likvidatsiia nepysmennosti sered dorosloho naselennia Ukrainy u 20-kh rokakh [Elimination of illiteracy among the adult population of Ukraine in the 1920s]: avtoreferat dysertatsii kandydata istorychnykh nauk: 07.00.01. Zaporizhzhia: Zaporizkyi derzhavnyi universytet. [in Ukrainian]

Korohod, B. \& Korohod, H. (1993). Zdisnennia polityky ukrainizatsii na Sumshchyni $v$ 20-ykh rokakh [Implementation of the policy of Ukrainization in Sumy region in the 1920s]. Sumy: Obltypohrafia. [in Ukrainian]

Kozyr, V. (2010). Finansova diialnist tovarystva «Het nepysmennist» [Financial activity of the society "Down with illiteracy"]. Materialy konferentsii «Aktualni problemy ahrarnoi istorii Ukrainy: mynule i suchasne» (Kyiv, 26-27 bereznia 2010). Kyiv: Natsionalnyi universytet bioresursiv i pryrodokorystuvannia Ukrainy. [in Ukrainian]

Kuksa, N. (2004). Likvidatsiia nepysmennosti v ukrainskomu seli pershoi polovyny 20-kh rokiv $X X$ st. [Elimination of illiteracy in the Ukrainian village of the first half of the 20 s of the XX century]. Visnyk Cherkaskoho universytetu. Seriia: Istorychni nauky. Cherkasy. Vyp. 61. [in Ukrainian]

Leshchenko, N. (1969). Z istorii narodnoi osvity na Ukraini v roky vidbudovy narodnoho hospodarstva [From the history of public education in Ukraine during the reconstruction of the national economy]. Ukrainskyi istorychnyi zhurnal. № 4. [in Ukrainian]

Molotkina, V. (1999). Likvidatsiia nepysmennosti v Ukraini v umovakh NEPu [Elimination of illiteracy in Ukraine in the NEP]. Naukovi zapysky z ukrainskoi istorii: Zbirnyk naukovykh statei: Pereiaslav-Khmelnytskyi derzhavnyi pedahohichnyi instytut im. H. S. Skovorody. Kyiv-Pereiaslav-Khmelnytskyi. Vyp.VII. [in Ukrainian]

Moroz, A. Likvidatsiia nepysmennosti $i$ rozvytok zahalnoi osvity trudiashchykh $v$ 1921-1925 rokakh [Elimination of illiteracy and the development of general education of workers in 1921-1925]. Ukrainskyi istorychnyi zhurnal. 1976. № 8. [in Ukrainian]

Nevinchana, I. (2005). Problema nepysmennosti ukrainskoho narodu v konteksti zahalnoievropeiskykh protsesiv natsiotvorennia (20-i roky) XX st. [The problem of illiteracy of the Ukrainian people in the context of European processes of nation-building (20s) of the XX century.] Visnyk Akademii pratsi $i$ sotsialnykh vidnosyn Federatsii profspilok Ukrainy. Naukovo-praktychnyi zbirnyk. Kyiv: FPU, № 5. [in Ukrainian]

Petrova, Ya. (2010). Organizaciya obucheniya vzroslyh v processe likvidacii negramotnosti $v$ SSSR v 1920-1930-e gg. [Organization of adult education in the process of eliminating illiteracy in the USSR in the 1920s and 1930s]: avtoreferat dissertacii kandidata pedagogicheskih nauk: 13.00.01. Samara. [in Rusiian]

Polozhennia pro shkoly dlia doroslykh (1920) [Regulations on schools for adults]. Fond R-5600. Opys 1. Sprava 118. Derzhavnyi arkhiv Sumskoi oblasti, Ukraina. [in Ukrainian]

Prohrama kraiovoho seminaru dlia likvidatora nepysmennosti (1924) [The program of the regional seminar for the liquidator of illiteracy]. Fond R-4563. Opys 1. Sprava 964. Derzhavnyi arkhiv Sumskoi oblasti, Ukraina. [in Ukrainian]

Prohrama shkil dlia doroslykh 1 stupenia (1920) [The program of schools for adults of 1 degree]. Fond R-5600. Opys 1. Sprava 118. Derzhavnyi arkhiv Sumskoi oblasti, Ukraina. [in Ukrainian] Svystovych, S. (2013). Diialnist hromadsko-osvitnikh obiednan Ukrainy (1920 - pochatok 1930-kh rokiv) [Activities of public educational associations of Ukraine (1920-early 1930s)]. Naukovi pratsi istorychnoho fakultetu Zaporizkoho natsionalnoho universytetu. Zaporizhzhia. Vyp. XXXVI. [in Ukrainian]

Tymchuk, L. (2015). Osvita doroslykh u navchalnykh zakladakh systemy likvidatsii nepysmennosti $v$ Ukraini (20-30-i roky XX stolittia) [Adult education in educational institutions of the 
system of elimination of illiteracy in Ukraine (20-30-ies of the XX century)]. Science and Education a New Dimension. Pedagogy and Psychology, III (24). Vyp. 48. [in Ukrainian]

Yepyk, L. \& Petrenko, N. (2018). Systema finansuvannia likpunktiv u $20 \mathrm{rr}$ XX st. na Sumshchyni [The system of financing illiteracy elimination centers in Sumy region in the 1920s]. Traektoriâ Nauki = Path of Science, 4 (8). DOI: 10.22178/pos.37-8. [in Ukrainian]

Yepyk, L. (2016). Kadrove ta materialne zabezpechennia kursiv liknepu na Sumshchyni u 20-i rr. XX st. [Staffing and material support of liknep courses in Sumy region in the 1920s.]. Naukovi pratsi istorychnoho fakultetu Zaporizkoho natsionalnoho universytetu. Vyp. 46. [in Ukrainian] Zvit pro diialnist tovarystva "Het nepysmennist" imeni Lenina (1926) [Report on the activities of the society "Down with illiteracy" named after Lenin]. Fond R-5601. Opys 1. Sprava 697. Derzhavnyi arkhiv Sumskoi oblasti, Ukraina. [in Ukrainian] 